\title{
O aprendizado de outras línguas e sua importância
}

\author{
Felipe de Queiroz NOPES $\bullet$ \\ Universidade de Santa Cruz do Sul (UNISC)
}

\section{RESUMO}

A conferência se inspira na fala da escritora Chimamanda Adichie, intitulada O perigo de uma única história, e no conceito de "local" da escritora Taiye Selasi para abordar a importância de se aprender outras línguas, visto que são elas, entre outros motivos, que fazem com que o indivíduo se sinta um local, já que o conceito de país é uma criação, mas toda experiência é real e local. Para retratar o papel das línguas na construção/coesão nacional, a primeira autora menciona a Suiça, país multilíngue que possui quatro línguas nacionais, sendo duas majoritárias que disputam, entre si, o papel de primeira língua estrangeira obrigatória a ser ensinada na escola, juntamente com o inglês. A discussão também destaca o papel do multilinguismo na promoção e manutenção de uma ecologia de línguas, finalizando com a segunda autora apresentando uma proposta concreta nesse sentido: a criação da Associação Iberoamericana de Linguística Aplicada (AIALA).

\section{ABSTRACT}

The conference is inspired by the speech of the writer Chimamanda

AVALIADO POR

Kyria Finardi

DATAS Adichie, entitled The danger of a single story, and the concept of "place" of the writer Taiye Selasi to address the importance of learning other languages, since they are, among other reasons, which make the individual feel like a local, since the concept of country is a creation, but every experience is real and local. To portray the role of languages in national construction/cohesion, the first author mentions Switzerland, a multilingual country that has four national languages, two of which are majorities which compete, among themselves, for the role of the first mandatory foreign language to be taught at school, along with English. The discussion also highlights the role of multilingualism in promoting and maintaining a language ecology, ending with the second author presenting a concrete 


\section{REVISTA DA ABRALIN}

proposal in this regard: the creation of the Iberoamerican Association of Applied Linguistics (AIALA).

\section{PALAVRAS-CHAVE}

Línguas locais. Experiência. Multilinguismo.

\section{KEYWORDS}

Local languages. Experience. Multilingualism.

O provérbio africano "Até que os leões tenham seus próprios historiadores, as histórias de caça continuarão glorificando o caçador" foi o exemplo usado pela professora da Universidade Federal do Espírito Santo (UFES), Kyria Rebeca Finardi, na conferência online proferida no dia 21 de julho, para fazer uma comparação com os idiomas nos quais as histórias são contadas. "Se a língua for sempre, por exemplo, o inglês, as outras línguas serão sempre as vítimas", comentou. Ou seja, é necessário darmos a oportunidade para que outras histórias sejam contadas em outros idiomas.

Segundo ela, da mesma forma que, se nos aproximarmos de um leão ou de uma leoa e cuidarmos desse animal, conhecendo-o mais de perto, certamente não conseguiremos caçá-lo ou matá-lo, se nos aproximarmos de outras culturas e línguas, também vamos querer preservá-las, divulgá-las e enxergá-las de uma maneira diferente. Sendo assim, Kyria ressaltou a importância de se aprender outros idiomas, dando como exemplo o esperanto, língua artificial criada pelo médico polonês Ludwig Lazar Zamenhof por volta de 1887, justamente na esperança de que pudesse salvar vidas e promover a paz entre os povos. "Ele imaginou que, criando uma língua que não pertencesse a nenhum local específico, mas que tivesse características das línguas faladas em vários países, ela poderia ser de todos e promover a paz e a comunicação entre os povos", contou a docente.

No entanto, mesmo sendo usado em mais de 120 países, o esperanto não foi capaz de ser apropriado e empregado para garantir a paz mundial. O motivo pelo qual o objetivo da criação dessa língua não tenha sido atingido está, conforme Kyria, relacionado à característica do próprio esperanto, qual seja, ao fato de que essa língua não é local e, portanto, não pertence a nenhum lugar. Para abordar a importância do local e sua relação com as línguas, Kyria passa então a relatar a sua experiência de vida em oito países, além do Brasil, onde morou, ainda que um dos principais motivos pelos quais ela não se sinta uma local ou nacional em todos esses lugares é o fato de não falar a língua de todos esses países. Entre eles, ela destacou a Suíça, onde morou por mais de um ano e realizou, na Universidade de Genebra, o estágio de pós-doutoramento sobre o papel das políticas linguísticas na internacionalização do ensino superior.

A escolha do país, porém, não foi por acaso, e sim pela diversidade linguística da Suíça e por representar aquilo que se imagina como um país multilíngue - são quatro línguas nacionais (francês, alemão, italiano e romanche), além de o ensino do francês e do alemão ser obrigatório nas escolas. 


\section{REVISTA DA ABRALIN}

A fim de entender o multilinguismo e o papel do inglês na Suíça, Kyria escolheu a Universidade de Genebra para realizar os seus estudos, já que a instituição não adota o inglês como língua de instrução, ao contrário das outras universidades avaliadas entre as 100 melhores do mundo, que estão ou em países anglofalantes ou são instituições que adotaram o inglês como meio de instrução.

Ao contar o pacto de coesão nacional feito na Suiça, onde os cantões deveriam ensinar alemão ou francês (as duas línguas majoritárias) como língua estrangeira na escola, Kyria comenta que esse pacto foi quebrado quando o Cantão de Zurique decidiu colocar o inglês como primeira língua estrangeira na escola, antes do francês. A escolha do inglês se deu por se tratar de um idioma mais fácil e que permitia a comunicação não só com suíços de outros cantões, mas também com estrangeiros. Desta forma, é possível perceber que o inglês, mesmo não sendo a língua nacional, oficial e estrangeira obrigatória na Suíça, provocou uma fissura no pacto de coesão nacional multilíngue suíço, indicando que qualquer modelo multilíngue deve considerar o papel do inglês, independente do status que essa língua tenha em determinado local.

Ao abordar o papel do inglês como língua franca hegemônica, Kyria cita dados de estudos (como, por exemplo, de Hamel, 2013) que mostram que não é apenas a língua (inglês), mas também o local da produção científica que determinam o aceite de artigos científicos, evidenciando a relação entre língua/local na produção do conhecimento. De acordo com a docente, citando a escritora nigeriana Taiye Selasi, a nossa história e a nossa cultura são reais, mas "os países são inventados". Ou seja, toda a experiência vivida é local e toda a identidade é construída pela nossa experiência.

Quanto à relação do local com a língua, Kyria ressaltou a visão sociocultural de língua, sugerindo que é através da língua que temos a possibilidade de fazer a mediação com a realidade. Usando como exemplo a língua dos esquimós, com mais de 17 palavras diferentes para designar a neve, enquanto que a língua portuguesa possui apenas uma, a professora frisou o papel importante da língua não só como mediação da realidade, mas também como potencial de criação da realidade e de uma experiência local enriquecedora.

Antes de dar a palavra para a professora da Universidade de Indiana, nos Estados Unidos, Laura Gurzynski-Weiss, Kyria finalizou salientando a importância de criarmos pontes e não muros por meio das línguas, visão essa reforçada por Laura, que enfatizou que perspectivas multi e plurilingues permitem derrubar muros e construir pontes em uma sociedade. Laura também apresentou, de forma sucinta, dados referentes ao espanhol, apontando ser essa a segunda língua mais falada no mundo (cerca de 580 milhões de falantes) e a terceira mais usada nos negócios, e falou sobre a criação da nova organização regional da Associação Internacional de Linguística Aplicada (AILA), a Associação Iberoamericana de Linguística Aplicada (AIALA), dedicada a promover o multilinguismo e as línguas da região - português, espanhol e línguas minoritárias, especialmente indígenas. A docente é membro do comitê executivo da AILA e a única integrante que fala espanhol e português, trabalhando para que a diversidade linguística no mundo seja refletida na Associação.

A conferência mostrou que falar mais de um idioma é, certamente, fundamental para enriquecer o nosso conhecimento, a nossa cultura, a nossa história e a nossa experiência de vida. É notável que o inglês predomina em muitos países, inclusive no Brasil, quando se pensa em aprender uma segunda 


\section{REVISTA DA ABRALIN}

língua, seguido do espanhol. Tanto que o aprendizado desses dois idiomas faz parte da grade curricular de muitas escolas brasileiras como opção de língua estrangeira. Mais do que nunca, a habilidade de falar e se comunicar em outra(s) língua(s) permite a inserção e o convívio com diferentes povos de forma mais intensa e apropriada, além de possibilitar diversas opções de estudo em outros países e mais oportunidades no mercado de trabalho, tanto nacional quanto internacional.

\section{REFERÊNCIAS}

O perigo de uma única língua. Conferência apresentada por Kyria Rebeca Finardi e Laura Gurzynski-Weiss [s.l., s.n], 2020. 1 vídeo (1h 18min 06s). Publicado pelo canal da Associação Brasileira de Linguística. Disponível em: https://www.youtube.com/watch?v=GXd50TMk9do\&t=2085s. Acesso em: 25 jul. 2020. 